\title{
CHRONOLOGY OF THE URBAN EXPANSION OF SHTIP
}

DOI: https://doi.org/10.18509/GBP2105031

UDC: 911.375.1:006.95(497.731)

\author{
Maja Lazarevska ${ }^{1}$ \\ Blagoja Markoski ${ }^{2}$ \\ ${ }^{1}$ Ministry of Transport and Communications of the Republic of Macedonia \\ ${ }^{2}$ University of "Ss. Cyril and Methodius" - Skopje, Faculty of Natural Sciences and \\ Mathematics, Institute of Geography, Macedonia
}

\begin{abstract}
The phenomenon of spatial expansion and sprawling of cities in one particular territory is a condition that has greatly influenced the contemporary city and society, from the physical/spatial aspect, social, as well as the aspect of urban development.

The topic of this study is the genesis and the matrix of the spatial development of Shtip and determining the cause-effect factors and results.

The main thesis of the study suggests necessity for introducing a program-spatial matrix/paradigm in the development, so as to regulate the spatial expansion of the urban web. The program-spatial matrix is associated with the segment of planning, or the introduction of the normative structure.

The work methodology is based on comparative analysis of the changes from a spatialphysical and a planning point of view. Due to the specifications of the region concerned, this study, in methodological sense, starts with providing documentary grounds, based on methods of collecting, documenting and analyzing the information found.

The conclusion of this study encourages the need for introducing a normative structure in the spatial development planning of cities in order to improve the spatial quality, the economic dynamics and the social cohesion.

The results of the study analyses ought to provide a clearer representation of the relations between the urban planning (spatial and general) and the space as well as the consequences of their implementation, or non-implementation.
\end{abstract}

Keywords: spatial development, spatial expansion, urban development, pole, axis of influence

\section{INTRODUCTION}

The topic of this study is the city of Shtip, a centre of a mesoregion according to Daskalovski and Markoski [3], i.e. a center of a macroregion on a national level according to the Draft Spatial Plan of the East Planning Region [1], a pole of development with great influence, appropriate to its position in the region, i.e. the spatial-physical context in the geographical surroundings, as a phenomenon with its own specific individual development. For better understanding of the issue, an analysis of the naturalgeographic, social-geographic and economic-geographic features of the space has been made. The spatial and urban city planning has been observed as a second segment. The city of Shtip is marked by nearly a hundred years of history of spatial planning. The spontaneous and non-regulated development of the urban web has been replaced by a process of urban development and urban planning, a process which started in the second decade of the twentieth century (1927). The planning documents are the result of the 
inconsistent social-political conditions that existed in that particular moment, as well as of the position and the significance of Shtip in that particular territory. From 1927 until today five urban plans have been adopted, each of them covers the city integrally and defines its development as such. The plans have different content and qualitative characteristics. They represent the atmosphere, the aspirations of the officials in charge and the actual relevant legislation. In this study, different planning treatments are separately discussed in relation to the adopted plans, their decision on the boundaries of the urban-planning area as well as the city boundaries. The goal is to analyze the process of spatial and urban expansion of the city, with a special emphasis on the cause-effect relationships arising from the physical conditions.

\section{STUDY AREA WITH BASIC GEOGRAPHIC CHARACTERISTCS}

The city of Shtip is located in the East Planning Region (Nomenclature of Territorial Units for Statistics - NUTS level 3), one of the eight non-administrative units - statistic regions which arouse by grouping the municipalities from lower rank in administrative units in the Republic of Macedonia. [2] (Decision on determining the nomenclature of territorial units for statistics - NUTS, adopted by the Government of the Republic of Macedonia, "Official Gazette of the Republic of Macedonia" No. 158 from 28.12.2007, the last amendments and supplements were made in January 2014 ("Official Gazette of the Republic of Macedonia" No. 10 from 20.01.2014). This planning region covers an area of $3.538 \mathrm{~km} 2(13,76 \%$ of the country's territory) and has a population of 151.858 ( $9 \%$ of the population in the Republic of North Macedonia). The region consists of the municipalities: Berovo, Vinica, Delchevo, Zrnovci, Karbinci, Kochani, Makedonska Kamenica, Pehchevo, Probishtip, Cheshinovo-Obleshevo and Shtip. [1]

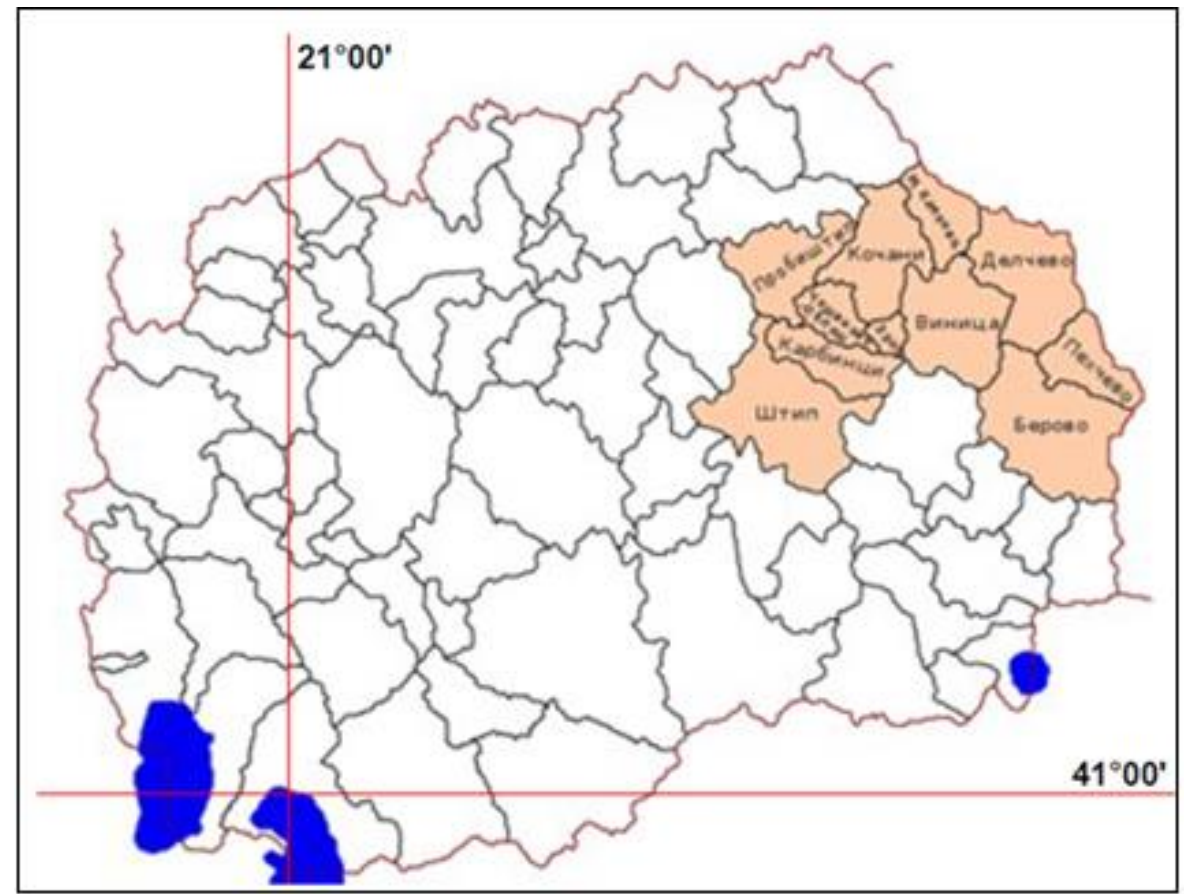

Figure 1. Map of the east region in Republic of North Macedonia, source http://www.eastregion.mk/

The municipality of Shtip is located in the middle course of the river Bregalnica, in the center of east Macedonia. Favorable features for the development of the city are the proximity of the main traffic corridors 10 and 8, as well as the position of the major traffic 
arteries of importance to the country and the region. The routes connecting the Vardar Valley and Skopje with the eastern parts of the country and neighboring Bulgaria pass through Shtip, for which the openness of Ovche Pole is particularly suitable. The natural suitable corridors for traffic communication are the Ovche Pole- Kochansko PoleDelchevsko Pole route in the east and the Ovche Pole-Kriva Lakavica Valley-Strumica Valley route in the southeast.

The city occupies the immediate area around Isarot on the riverbanks of the Otinja and Bregalnica, gradually rising up the slopes of the surrounding hills, giving the area an amphitheatrical appearance.

The relief structure of the municipality is characterized by various orographic features. From a morphostructural point of view, the following forms appear: flat terrains of Ezhovo Pole, parts of the valley of the rivers Bregalnica and Kriva Lakavica, hilly terrains of Mount Mangovica in the north, Serta and Konechka in the southwest and hilly and mountainous terrains of Mount Plachkovica in the east.

The city of Shtip is located on the erosive riverbanks of the rivers Bregalnica and Otinja, between the hills Isarot $(395 \mathrm{~m})$ and Merite (420) to the west, Kumlak (455 m) to the south, Karakush $(425 \mathrm{~m})$ and the hills of Plachkovica with the highest points of $384 \mathrm{~m}$, $345 \mathrm{~m}, 339 \mathrm{~m}$ and $327 \mathrm{~m}$, which close the space to the east. To the north and southwest along the valley of the river Bregalnica and northwest to Ezhovo Pole the area is flat and wide open, with an altitude of up to $300 \mathrm{~m}$. The area of Ezhovo Pole, Prebeg, Gladno Pole and Dolni Bunar and that of the riverbank of the Bregalnica are mildly rolling areas with favorable topographical features. The area to the north and east is a distinctly hilly area intersected by gullies and prominent erosion processes. A striking feature of the area is the flow of the river Bregalnica. It flows through a gorge between the Merite and Isarot localities, and then erosive riverbanks appear again as it continues southwards. The river Otinja flows into the gorge of the river Bregalnica from the east. In summary, it can be emphasized that the area clearly distinguishes three parts: hilly terrain (10\%), slopes $(30 \%)$ and flat terrain $(60 \%)$.

The wider area of the city has a complex geological structure. To the east and northeast, in Ezhovo Pole and Prebeg, the terrain is built of sandstone, clay, and marl. The Merite, Isarot and Kumlak hills are made of granite, and the Pluzhdino locality is composed of marly clay, sand and gravel. The terrain at the Letishte locality consists of deluvial and proluvial sediments, while alluvial sediments cover the terrain along the river Bregalnica. The territory of the municipality is dominated by temperate continental climate with some influence of the modified Mediterranean climate through the valley of the Bregalnica. The average annual temperature is $12.9^{\circ}$. There are 72 days per year with ice occurrences. The average duration of sunshine is particularly striking, with 2376.9 hours per year. The area is dry, with $506.1 \mathrm{~mm}$ of annual rainfall on average. The summer period is marked by heavy rains. The average annual humidity is $67 \%$. Fogs are a rare occurrence. The dominant winds are those from the northwest $(5.2 \mathrm{~m} / \mathrm{sec})$ and southeast $(6.7 \mathrm{~m} / \mathrm{sec})$.

From a hydrographic aspect, the city lies at the estuary of the Otinja River into the Bregalnica River. The Bregalnica, with a flow rate of $17.9 \mathrm{~m} 3 / \mathrm{sec}$, is the main recipient of water in this area. In front of the city of Shtip, the river flow is flat with large meanders, and in continuation of the flow through the city a typical gorge is formed, and then downstream to the south it continues through a large erosive riverbank. The Otinja springs from Plachkovica $(0.16 \mathrm{~m} 3 / \mathrm{sec})$ and has the character of a torrential stream, with a large amount of water and a high potential torrential capacity. The riverbed of the Otinja is regulated in a length of $1600 \mathrm{~m}$ through the city. The wider area of the city is poor with 
natural water sources. There is only one spring with a yielding property of $11 / \mathrm{sec}$. To the south-east of the city there is an occurrence of thermal waters at the sites of Kezhovica and L'dzhi. The yielding properties of the springs are low, 1-1.51/ sec, with a temperature of 52-60 degrees. Drilling has enabled a capacity of $201 / \mathrm{sec}$. Kezhovica is a spa recreational centre. In the wider northeast part of the city there are 14 gullies with a torrential character which are not regulated. The water supply in the city is provided by the groundwater in the Fortuna, Shtip Lake and Ribnichki Cheshmi sites, which are adjacent to the Bregalnica, and their level is directly dependent on the level of the river flow, as well as the Zletovica system (first phase of water supply which is realized). With the construction of the Kalimanci reservoir on the Bregalnica there is no occurrence of floods.

Shtip is situated on the boundaries of the Ovche Pole agricultural area, marked by ploughed lands, vineyards, industrial crops and pastures. In the wider area, heterogeneous soil types are encountered, with the predominance of the second (in the northern flatlands) and third solvency class (to the east, west and south of the city on the slopes of Plachkovica). Soils of the first solvency class are partially present (alluvial lands northeast of the city along the Bregalnica, but on small areas). The agricultural land in the municipality of Shtip covers an area of 34762 ha, of which 13859 ha are arable land and 20903 ha are pastures. (Draft Spatial Plan of the East Planning Region)

The forest land in this area occurs in small enclaves in parts of steeper and more concealed places above $1000 \mathrm{~m}$. Up to $500 \mathrm{~m}$ this land is degraded, destroyed and converted to pastures. Tall trees encompass a very small percent. The area is dominated by steppe-like pastures with high anthropogenic impact. They are rich in terms of flora, with a large number of endemic species, and are among the most important areas for winter grazing. As far as vegetation is concerned, the overall impression of the region is poor, desolate, deforested with dominant agricultural character and devastated forest areas on the slopes of Plachkovica. In the domain of urbanization and settlement system, the urban settlement occupies a special place, both within the municipality, and in the wider region and country. This region is no exception to the previously analyzed when it comes to the prominent process of deagrarization of rural settlements, with the occurrence of displacement of settlements (out of 43 rural settlements, 34 are active, while 9 villages have been displaced since 1991).

This process of depopulation has a tendency of growing. The process of urbanization is intense with elements of: highly concentrated urbanization type, large differences between the degree of urbanization and general development, great differences in size and in functional facilities of the settlements, prominent occurrences of illegal buildings, grouped into settlements of up to $30 \mathrm{ha}$, which strongly influence the concept of city development. The interregional analysis of the correlation between the level of urbanization and the value of GDP shows that the East Planning Region is in 4th place according to the level of urbanization, compared to the other 7 planning regions. [1] [6] [11] [13] [24]

\section{METHODOLOGY FOR RESEARCH}

specifics of the study area, the paper, in methodological terms, begins the first phase with establishing a documentary base by applying methods of collection, gathering, documenting and analysis of the gathered data, or method of acquisition. The primary sources are composed of spatial plans, urban plans, cartographic, cadastral, and other plans released by official state institutions, local self-government, State Archive, Archive 
of the City of Shtip, Agency for real estate cadastre, planning institutions etc. Scientific papers, comments from scientific magazines, publications, monographies are also used as secondary sources.

The data gathered from different sources and of varying formats \& structure has been processed by methods of generalization and systematization in order to produce comparable parameters which can be evaluated with the same approaches.

Comparative analysis is the primary method implemented to track and evaluate the changes in the spatial and planning aspect. Other relevant methods which have also been used are statistical, analytical and specialized software programs. For illustrative purposes tables and diagrams are applied.

The results collected in the research are presented as individual findings and in a cumulative view. The conclusions and recommendations of this research are a synthesis of the results and their comparison with the hypotheses and basic theoretical postulates.

\section{RESULTS}

\section{Chronology of the urban expansion}

Archaeological findings confirm the extremely long history of Shtip and its surroundings. The name Astibo is mentioned for the first time by the ancient chronicler Polienvo (III century BC). Then, it is mentioned as one of the most significant Paionian centers in written documents from the 1st century $\mathrm{AD}$, during the reign of the Roman Emperor Tiberius. Astibo (the old name of the Bregalnica) is mentioned again in Tabula Peuttingemiana (ancient map from the 4th century), as a settlement on the road to Stobi Pautalia (Kyustendil) - Serdika (Sofia). The settlement existed both in the late ancient and early Byzantine times, probably under the name of Stipeon, and in the Middle Ages the settlement was named Shtip. From 976 to 1014 Shtip was located within the borders of Samuil's state, afterwards it became part of Byzantium, Bulgaria, and Serbia until the arrival of the Turks towards the end of the second half of the 14th century when the medieval Shtip was finally conquered by the Ottomans in 1395.

The city is mentioned in 1620 as an Episcopal center. In 1661 the Turkish travel writer Evliya Çelebi went through the city and described it in his travelogues - "at that time Shtip was one of the economic and spiritual centers of the Christians in Macedonia." Evliya Çelebi also mentioned that he had visited the old part of Shtip (Novo Selo) and wrote that the seat of the Metropolitan bishop of Kyustendil (Kanasian), Kratovo and Shtip was located there. In the 17th century Shtip had several inns, 540 shops and a bedesten, but the real development of the city began in the late 18th and early 19th centuries, when the city played a significant role in the development of trade between the seaside towns of the Aegean Sea and the inland of the Balkan. [26] [15] [16] [5] [23] [22]

\section{Adopted urban plans}

The planning period of the city's development began with the first plans made after the liberation from the Ottoman Empire, more specifically, after 1927. Since then, four urban plans have been adopted for Shtip in which the city space is treated integrally, and one is in the process of being adopted:

- Detailed Plan from 1927, revised 1941-42 (1:500);

- General Urban Plan, prepared by Nikola Dobrovikj, adopted by the Council of the Municipality in 1963;

- Basic Urban Plan - Amendments from 1984; 
- General Urban Plan - Amendments from 1999;

- Draft General Urban Plan (in the process of adopting)

\section{Detailed Plan from 1927, revised 1941-42}

The first official planning document for the city of Shtip is the Detailed Plan from 1927, developed when the city was within the then Kingdom of the SCS. There is not much data associated with this planning document. It was made as a geodetic survey map, with a scale 1:500. In the archive of the municipality of Shtip, the basic design data of the plan are available on 8 sheets, but in very poor condition [4]. Regarding the legislation, according to the periodization of Siljanoska, the plan belongs to the "period from 19141948: a period when the urban activity and the legislative material are established, through which an integral treatment of all aspects important for control of the spatialphysical development of the city is ensured " [18]. When the plan was adopted, the city authorities began with activities for its implementation. In this period, the city had about 15.000 inhabitants [9] [25].

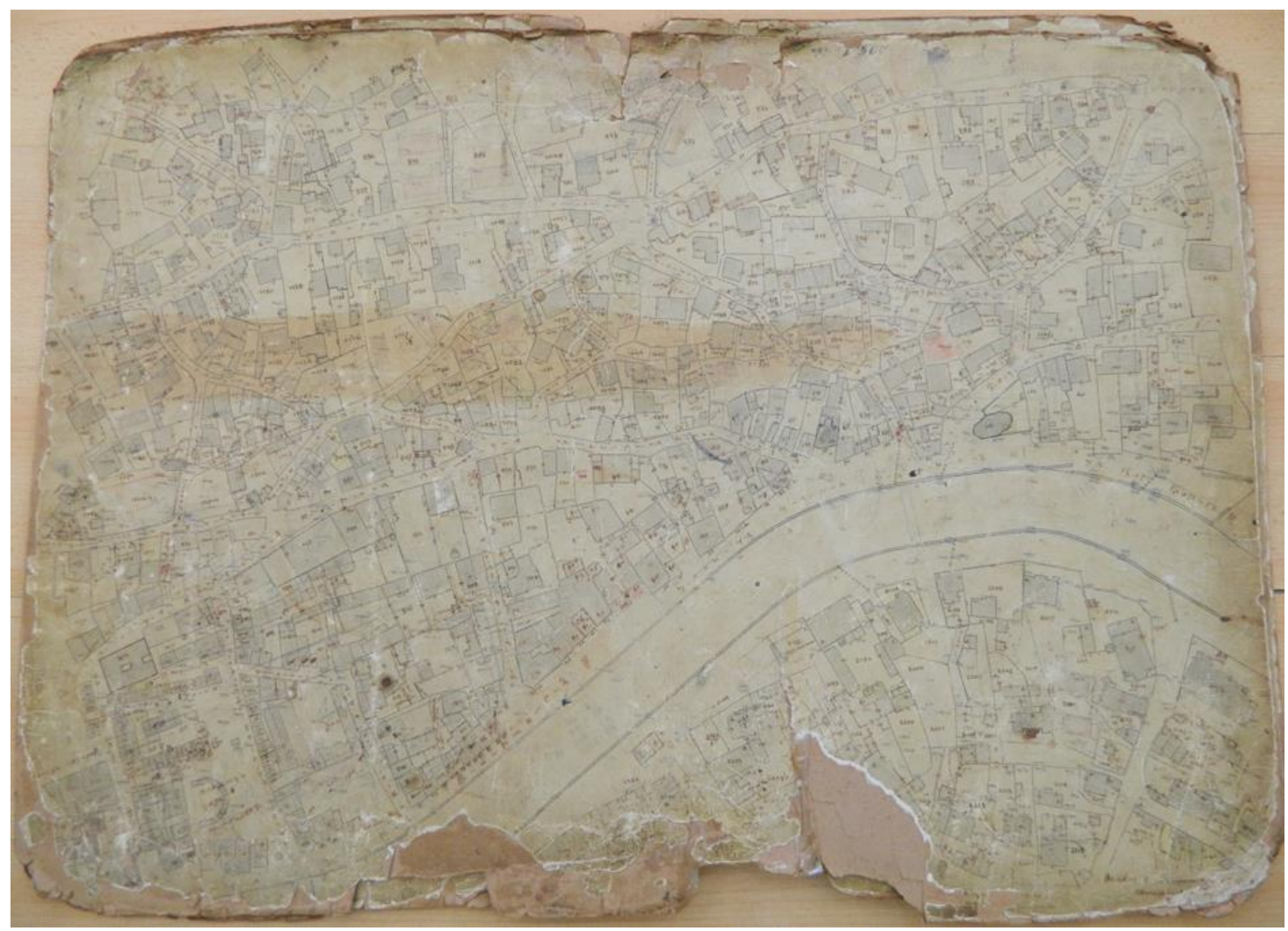

Figure 2: Detailed Plan from 1927 (revised 1941/42), sheet no. 6. Source: Municipality of Shtip

From an administrative-territorial aspect, the city was the centre of the Bregalnica (Shtip) district until 1965, when the districts as secondary territorial-administrative units were abolished. The plan covers an urban area of approximately 97 ha [4]. 


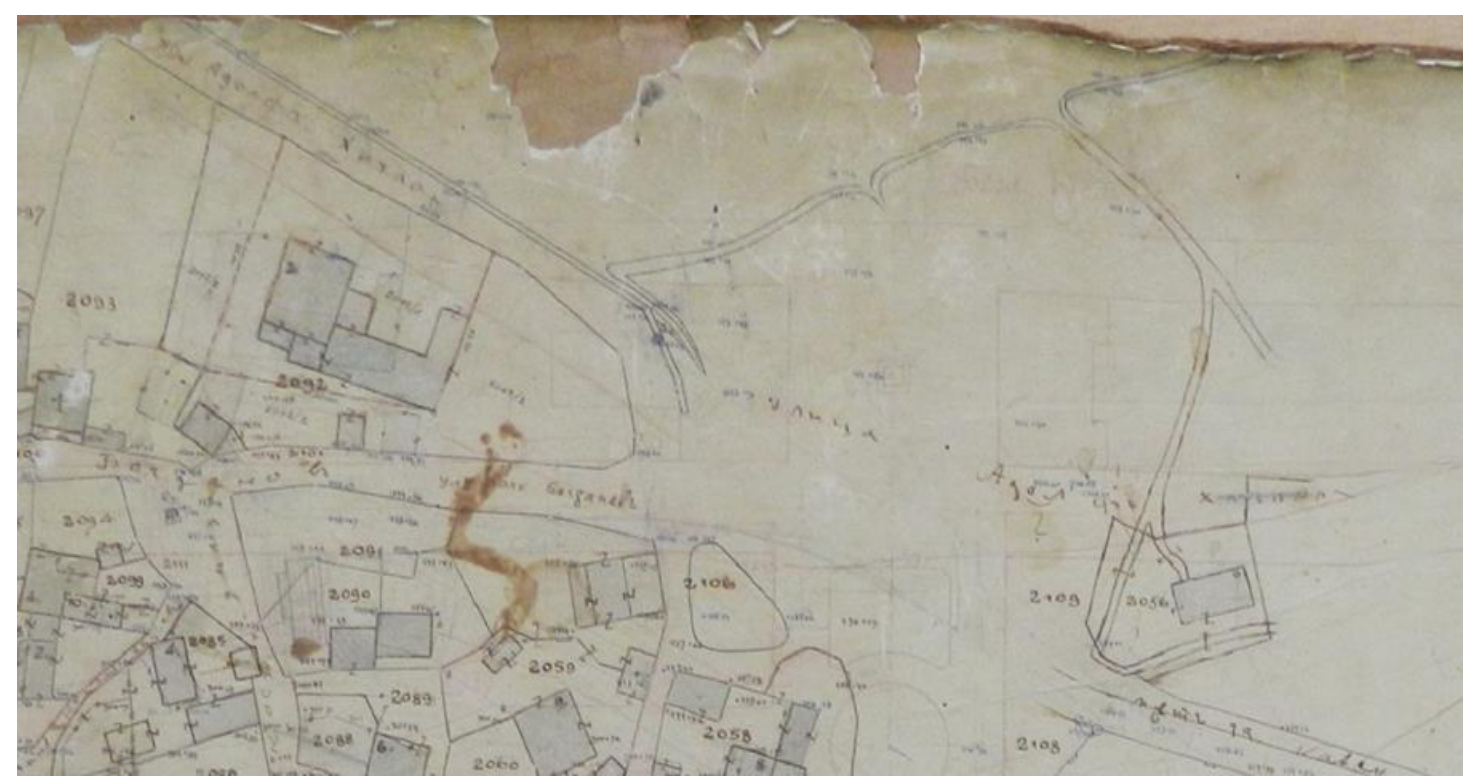

Figure 3: Fragment with Adolf Hitler Street from the 1927 Detailed Plan. (revised 1941/42). Source: Municipality of Shtip

\section{General Urban Plan (GUP), 1963}

The General Urban Plan of Shtip adopted in late 1963 represents a revolutionary vision for the development of the city. It was made in specific post-war circumstances when the reconstruction of the ruined city began. The process of intensive construction of industrial facilities, housing and socially important facilities began in the period 1950-55. In order to ensure the planned realization of the further development of the city, a General Urban Plan was being developed. The author of the plan is Nikola Dobrovikj, a well-known Belgrade architect. The plan was intended for intermediate application, i.e. elaboration with detailed urban plans, which were characterized by direct transfer of the planning solution to a larger scale, without further analysis of adaptation of the concept of the existing state plan and the physiognomy of the terrain, which is perceived as one of the major drawbacks of the plan. Unfortunately, the base maps of this important planning document are no longer available. The plan data are taken from the documentation base of the subsequent plans. The planning area generally follows the existing state of the city, i.e. it stipulated only small expansions. This issue is now being criticized, as it was quickly proved that analyzes of the future development needs of the city were not well understood (given the importance and role of the city in the wider area), and the city tissue began to expand very quickly beyond the boundaries of the planning area, especially to the north of the city. The visionary shaped components are a major qualitative element of the plan. The Belobrd Prospect, located on the right bank of the Otinja, is significant for its spatial concept with highly emphasized physical structures, which, through total reconstruction, resolved the issue of important buildings with central city functions and residential buildings, in place of poor quality housing stock. The plan also has original ideas for resolving infrastructure systems, such as entering the city through a tunnel, relocating and running the Otinja outside the city, to the north of the city, through a tunnel as well. The construction of the city via the reconstruction of the existing tissue was partially realized in smaller intakes on the southern slopes of Belo Brdo and the central area.

Smaller complexes and settlements were built in the period 1960-1970, but they were characterized by inadequate levels of planning and implementation. In the period after 1971 the construction of large residential complexes for 7.500 residents began. The 
planning and constructing of newer residential settlements was implemented with partial urban solutions, gradual improvement in the quality of urban documentation and technical documentation for infrastructure systems, but without a single concept of the city development as a functional whole. This created problems in the planning, development and implementation of functional facilities in the area.

Regarding the legislative framework, the plan was adopted in accordance with the 1953 Law on Urban Planning, which Siljanoska classifies in the "first generation" of urban laws, while Korobar classifies it in "a period of further decentralization of society and the emphasized influence of world experiences." [18][14] The process of migration of the population from the rural areas to the city was distinctively noticeable. In 1961 the city had 20.269 inhabitants. According to the census in 1981, it had 36.230 inhabitants, which is an increase of about $79 \%$ over a period of two decades. This phenomenon produces problems and collisions in the organization and the utilization of the land in the city, and therefore, the process of drawing up the Basic Urban Plan was initiated. The planning area of the GUP is approximately 630 ha (obtained by drawing the boundaries of the cadastral surveys from 1958) [11] [13].

\section{Basic Urban Plan - Amendments from 1984}

In order to perceive all aspects relevant to the existing situation and determine the development of the city, a complex systematic analytical approach was elaborated with a development of a spatial plan of the city and its territory. During this period Shtip is in intensive urbanization.

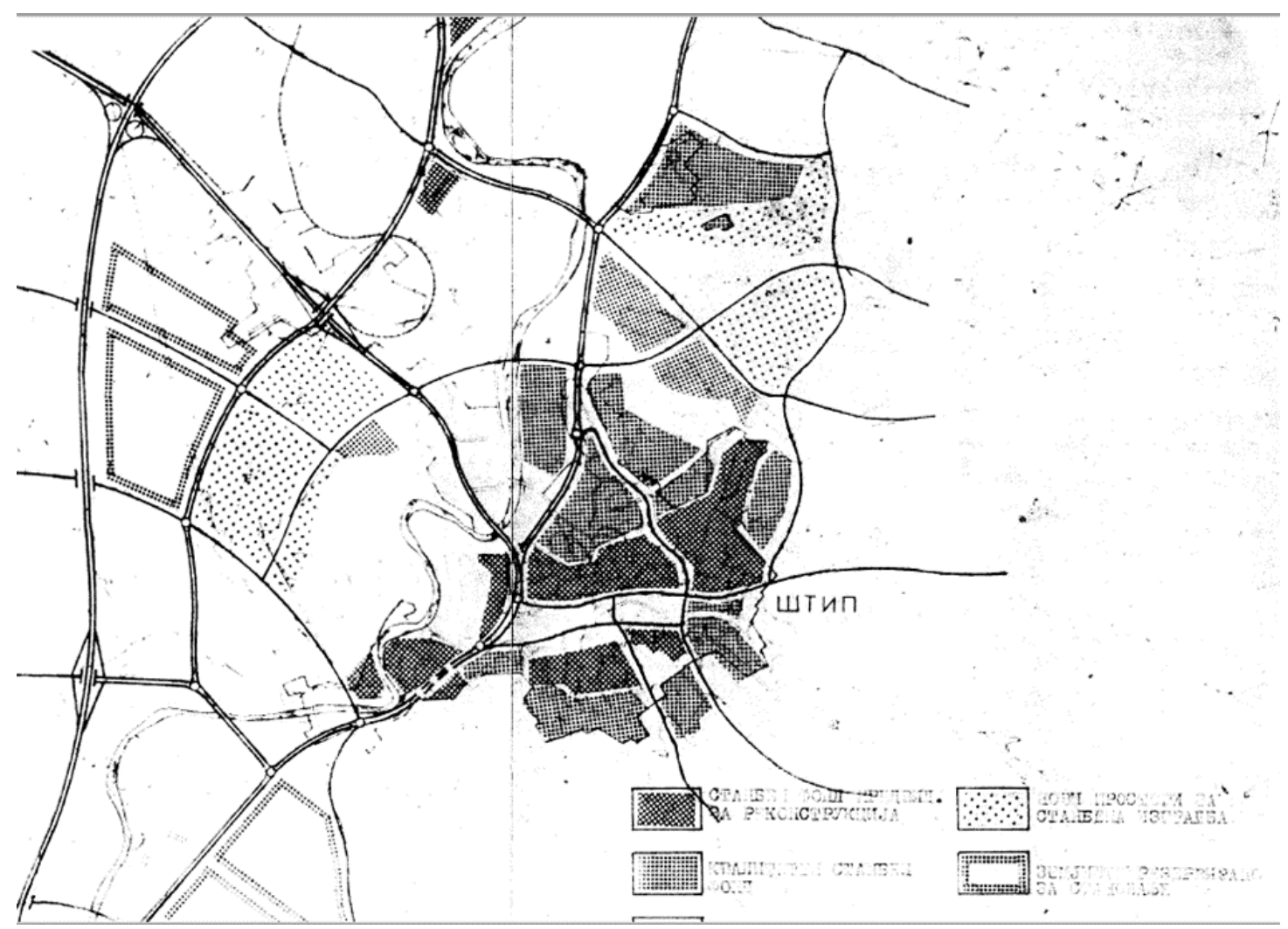

Figure 4. Basic Urban Plan - Amendments from 1984. Graphic appendix of the housing facilities Source: Municipality of Shtip 
The legislative framework for adopting the plan is defined by the 1978 Law on Spatial and Urban Planning, which Siljanoska classifies in the third period of legislation or "the period of enlarging the control instruments important for shaping the city space", while Korobar includes it in a "period of organization of the urban activity within the whole system of social planning" [18] [14].

Following the demographic trends, the spatial plan stipulates an increase of the population in the municipality of Shtip (encompassing the two present-day municipalities of Shtip and Karbinci), with a projection that in 2000 it will have 60.000 inhabitants, of which $50.000(80 \%)$ will be in the city itself.

This plan was developed at a time when "the socio-political and economic system is characterized by unidentified ownership of the means of production and of the more significant material goods, as well as the contractual economy." [11] [13]

The spatial plan treats the city of Shtip as one of the poles of development in the Republic of Macedonia, which should carry the role of a development generator in the East Planning Region. With regard to the degree of urbanization, the high rate of $73.6 \%$ in 1978 , the plan predicts that it will grow to $80 \%$ by the end of the planning period in 2000 (well above the national average of $70 \%$ ). The programming concept for an optimal settlement system is based on the following principles:

- Decentralized type of urbanization in conditions of higher quality of urban standard;

- Stimulating functional differentiation of settlements, avoiding duplication of capacity;

- Planned aiming of population growth with spatial and economic development plans, environmental factors, specific role in the settlement system, etc.;

All this results in the planning of the municipality development based on a polycentric settlement system, which includes:

- An urban center with $80 \%$ of the population living there, as a carrier of social development;

- Semi-urban center - local center, nuclei as the main carriers of urban and spatial development, functionally equipped with elements of urban standard and capacities of secondary and tertiary sector, in order to reduce population pressure on the city;

- Rural centers, village community centers, with lower-level equipment, planned as future development centers and functional gravity poles in the immediate surroundings;

- Other rural settlements, for which a total depopulation is stipulated by the end of the planning period, i.e., $6 \%$ of the total population will live there.

Methodologically, the approach builds on the theory of a development centre in the regional planning. "These centres have three functions: a service centre function, an innovation centre function and a centre for encouraging development, a function of a social integration point." [21]

The plan places particular emphasis on industrialization, which it plans to develop within the two existing zones (the first extending between the city and the existing train station to the Tri Chesmi settlement, and the second along the road to Radovish, adjacent to the city). The existence of the railway with the existing passenger and freight train station in the city is of importance. The planning solution separates the two stations: freight and passenger, i.e., a new location for the passenger station is determined. The freight station provides direct connection to the industrial facilities in the "Sever" zone [11] [12] [13]. The BUP was developed as a typical zoning plan with great inflexibility when it comes to the appearance of functions and uses other than the basic zone, which in 
implementation has proved to be a negative feature and has produced unintended development events.

The urban area of the plan covers an area of 2180 ha. The amendments to the Basic Urban Plan bring about development directions based on analyzes from the spatial plan. The basic goals of the Plan are: optimization of the size, structure and functions of the city organism; appropriate spatial dispersion of the housing, working and recreational areas, with maximum preservation of the quality of life and rational use of space; determining the optimal housing standard; planning optimal solutions for infra and supra structures; creation of a system of green park areas and protection and improvement of the environment. The analyzes show that unjustified planning expansion of the city boundaries has been made, as can be seen from the following data. A residential area of 430 ha is planned for residential use, with housing contents of approximately 100 ha or together with future housing space after 2000 - 664 ha (including contents of general standard, local centers ...), $70.3 \%$ of which was completed at the end of the planning period. The working zone is planned on an area of 330 ha (about 50\% is realized). An area of about 510 ha is planned for parks, greenery, sports and recreation (about $44 \%$ is realized). The biggest difference between the planned and implemented situation is for central functions-facilities of social importance, i.e., of 75 ha planned, only 30 ha are realized. The city is undergoing a process of emphasized de-agrarization. The prediction of the plan for suburban settlements to be transformed into development centers with an increasing number of inhabitants, with a tendency to merge with the urban settlement, did not come true (Tri Chesmi, Chardaklija and Karaorman). The planned population density is 129 inhabitants / ha. [10] [11] [13]

\section{General Urban Plan - Amendments from 1999}

The General Urban Plan - Amendments from 1999 was drawn up as a revision of the planning solution from the Basic Urban Plan from 1984. The plan is a development document with indirect application through detailed urban plans, adopted in accordance with the 1996 Law on Spatial Planning and Urban Planning. The following are the basic continuing goals that apply for the period covered by this plan:

- Optimization of the size, structure and functions of the city organism, depending on the system of settlements in the municipality, the real city opportunities and respect for all the advantages of a regional development pole and a significant center in the urban system of the country;

- Appropriate spatial dispersion of the economic and non-economic capacities, while respecting the principle of coordinated compositional design of housing, working and recreational spaces, with the greatest possible preservation of living conditions as an important prerequisite for rational use of urban space;

- Optimal protection of the historical, cultural-historical and architectural heritage, but also their inclusion in modern life, respecting their values and eliminating the opportunities for them to become an obstacle to the harmonious development of the city;

- Protection against natural, technical, military and other disasters;

- Rational land use;

- Coordinating the interests of landowners and land users with guidelines for resolving potential conflict situations.

The plan covers an urban area of 2.039 ha, with a planning period of 10 years, i.e., a development projection by 2010 . This plan, compared to the previous one, takes up less 
space by 141 ha. The difference is due to the elimination of the heavy industry area covered by the "Jug" industrial zone and the protective greenery, and an increase in the area is predicted in the residential settlement of Sveta Nedela in the east (cluster of illegal construction of about $30 \mathrm{ha}$ ). The planned number of inhabitants by the end of the planning period in 2010 is 50.546, and in the rural settlements it is 5.000.

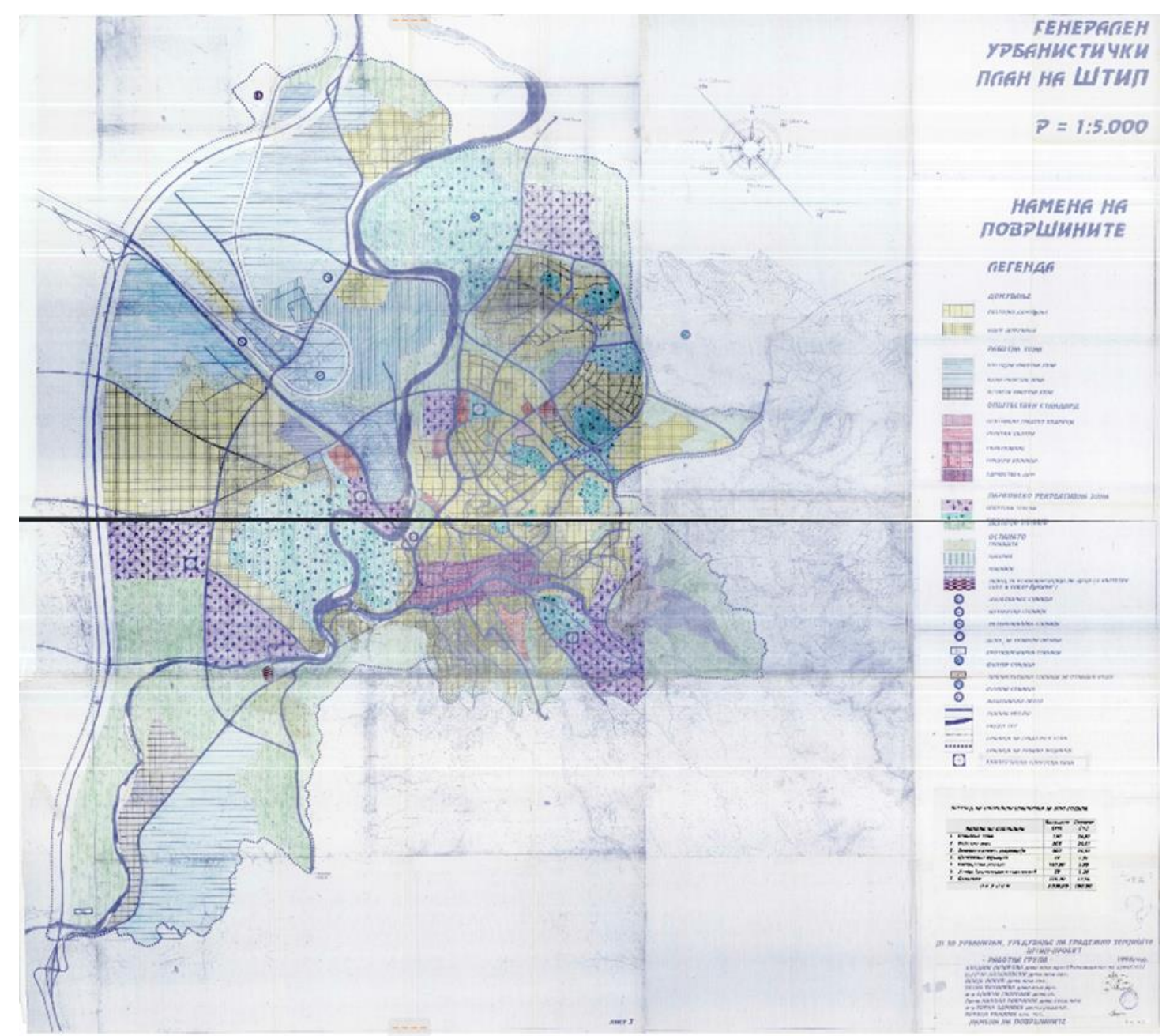

Figure 5: General Urban Plan - Amendments from 1999.

Graphic appendix - functions of areas. Source: Municipality of Shtip

The observations of the housing needs of Shtip in 2000 stipulated by the 1984 BUP were partially overcome in 1991 in terms of useful living space per capita and number of housing units. The plan achieves an average population density of 92 inhabitants / ha in 2010.

In terms of the construction system, the open system is predominant, as a way of urbanization in the second half of the twentieth century, and in the central parts a small scope closed system is also present. The basic organization of the housing zone is based on a planning-territorial unit called a residential or local community with $2.500-5.000$ inhabitants covering an area of 15-30 ha which includes complementary housing contents. In the concept of spatial organization of the city there are three levels of centers

- Local community center (predicted in every local community)

- Regional center (predicted in three of the five districts) and 
- City center (confirming the existing city center to perform functions of a higher and better quality level, complemented by functions of a regional nature).

The urban area organization differentiates three basic functional zones. Their location in terms of field conditionality is considered favorable, while their relation is not quite in line with the theoretical principles of the plan. The residential and working zones have a favorable mutual relation, with secured traffic links, with the Bregalnica riverbed between them, which is considered an advantage. The recreational zone is divided into sections which are stipulated to be in the periphery of the urban area i.e., the periphery of the residential zone, due to the impossibility of the environment and biological infrastructure to be infiltrated in the urban tissue more effectively.

Analyzes made for the planning purposes predict that the area of 508 ha planned for the working zone will not be feasible (not even $10 \%$ more of the existing state), but the justification for that is taken from the planning aspect, in order to purposefully occupy the space so as to prevent illegal construction. It should be noted that the plan defines a wider urban area, which reserves space for future development and a construction area smaller than the urban area.

Among the values created in the city that appear to be factors limiting the spatial development are clusters of illegal residential buildings in the industrial zones "Zapad" to the left and "Sever" to the right of the Shtip-Skopje route. Of these, the zone on the left of the road has the potential to integrate into the planning solution covering an area of about 40 ha, while the cluster in the industrial zone "Sever" cannot be integrated with residential function.

A qualitative factor of spatial development is the great area the city has already occupied. The existing monocentric model of the city limits the possibilities for expansion of the city centre, restricting its capacities and possibilities for it to develop along with the growing needs of the city. Expanding the urban web is predicted to the north and east. In order to overcome this situation, a decentralization of public functions is stipulated in the definition of the balanced development of the city, through the introduction of a system of centers. In addition to the city center, which is at the highest level, it is planned to develop larger local centers and to complete additional contents in the urban areas.

In the urban image the lack of green park areas is clearly expressed, as well as their inadequate distribution and the lack of connection within an organized system in the structure of the city. The current situation gives an average of $3 \mathrm{~m} 2$ per capita, which is a very low average given the planned norm of $25 \mathrm{~m} 2$ per capita. The plan stipulates an increase of green park areas with new sports and recreational belts along the rivers and their connection by line greenery with park-forest belts in an organized system, with planned areas of 500 ha (the inventory of 1997 established 226,1 ha) [13].

\subsection{Draft General Urban Plan 2014-2024}

The Draft General Urban Plan of the City of Shtip has been launched in 2014 and is still in the process of being adopted, i.e. it has no legal force (with planning period 20142024).

The manner of land use within the planning scope is conditioned by the created values and factors that synthesize the situation. Here we are primarily concerned with factors of demographic, economic, traffic, legislative-administrative, health-social and other aspects. With the good traffic connection, location, demographic growth and development, good position of the housing, working and recreational zones for the population, there is a need to develop new urban plans according to the current legislation 
that determine the manner of land use within the planning area scope. Within the system of settlements in the region, the city of Shtip is planned to be a primary urban center, together with Kochani and Strumica. The capital interest of the city of Shtip is to develop the whole system of settlements in the region, to reduce the migration flows and the population growth not to go faster than the possibilities to meet the needs of the people. On the other hand, the distribution of economic capacities in the city is designed to be in a radius favorable for daily labor migration, thus achieving a favorable relationship between working and living space with an adequate traffic and communications system to efficiently manage spatial distances with a fundamental goal - integrating into a single functional and spatial city system and its narrower and wider surroundings.

In the process of drawing-up the Draft GUP Shtip 2014-2024 the most important goals in the preparation of the plan are:

- the formation of the identity of the City as a whole and of individual parts,

- efficient organization of the elements in the space, so as to serve the needs of the citizens,

- efficient traffic organization,

- environmental protection,

- activation of the parts of the city which have not been encompassed by the previous GUP of the city of Shtip from 1999,

- raising the quality of urban infrastructure, especially in the under-urbanized areas.



Figure 6. Draft General Urban Plan. Graphic appendix - inventory of construction land - existing condition in 2014. Source: Municipality of Shtip 


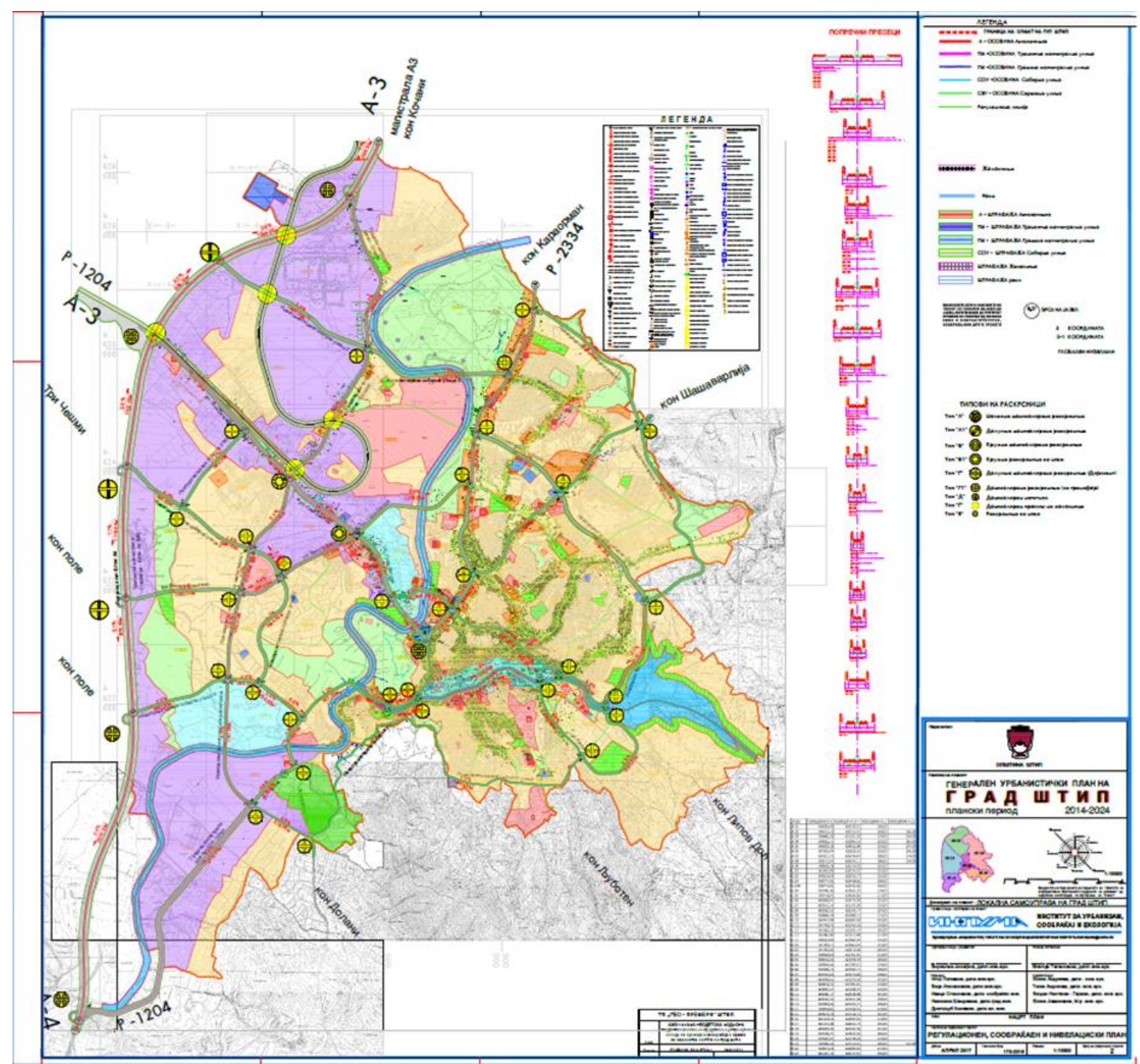

Figure 7. Draft General Urban Plan. Graphic appendix - synthesis plan. Source: Municipality of Shtip

The plan covers an urban area of 2292.13 ha, with a planning period of 10 years, i.e. a development projection to 2024. For the needs of the plan, a demographic analysis was made, which estimated the total number of inhabitants at the end of this planning period to be 58.427. This was taken as a starting point for the calculations (including students from the Goce Delchev University in Shtip).

The basic territorial division is performed according to the defined primary street network of districts, quarters and blocks. The city is divided into five districts (east, west, north, south and center), and each district is divided into an appropriate number of quarters. Within the quarters, smaller spatial units, i.e. blocks, are formed, which are also units for preparation of Detailed Urban Plans.

Land use designation in the General Urban Plan is done with the purpose class system according to Articles 24-33 of the Rulebook on Urban Planning Standards and Norms ("Official Gazette of the Republic of Macedonia", No. 142/15, 217/15, 222 / 15, 228/15, $35 / 16,99 / 16$ and 134/16). [17]

With regard to the represented specific zones in this draft plan, the balance is as follows: housing 926 ha, with planned density of 158.55 inhabitants / ha, commercial and business purposes 47.55 ha, public institutions 110.38 ha, production, distribution, services 523.55 ha, greenery, sports and recreation 324.29 ha. [10]. 


\section{DISCUSSION-ANALYSIS OF THE URBAN EXPANSION}

The development line of the territorial expansion of Shtip reflects the aggregate response of several variables. In the wide range of factors of influence, the dominant position is taken by the socio-political environment with a pronounced dynamics of change, the role of the city in the administrative-economic-functional context and its significance at the level of a certain territory, the legislative framework, the planning approach, the existing structure as a construction fund and conditions for implementation of the planning solutions.

\section{Analysis of the fluctuation of the population number}

Considering the demographic analyses in the planning period of the city, the part referring to the fluctuations of the number of the population, we come to the conclusion that when it comes to this issue, the city is going through several periods with different dynamics. The first period is from the beginning of the twentieth century until 1948, when the number of the population showed a constant decline, so that in the course of fifty years the number of inhabitants decreased twice the amount. Of course, this decline is the result of the two world wars.

In the period after 1948 the number of population began to increase, so from 11361 in the 1948 census it reached 20269 inhabitants in 1961, i.e.it increased by 46\%. This trend of constant growth continued until 1981 (33\%), and then the population growth was less intensive $(18 \%)$. As of the last census, growth has been reduced to a minimum average of $1.9 \%$. It is concluded that in the period from the second half of the fifties to the eighties of the last century the dynamics of growth is the highest, and the number of population in the planned period of 1913-2002 has an almost threefold increase. [1] [6] [9] [10] [11] [13] [15] [16] [25].

Table 1. Population dynamics in the city of Shtip in the censuses from 1899 to 2002

\begin{tabular}{|l|l|l|l|l|l|l|l|l|l|}
\hline year & 1899 & 1913 & 1948 & 1953 & 1961 & 1971 & 1981 & 1991 & 2002 \\
\hline $\begin{array}{l}\text { number of } \\
\text { population }\end{array}$ & 20.900 & 15.314 & 11.361 & 13.845 & 20.269 & 27.224 & 36.230 & 42.826 & 43.652 \\
\hline$\%$ & & $26 \downarrow$ & $26 \downarrow$ & $22 \uparrow$ & $46 \uparrow$ & $34 \uparrow$ & $33 \uparrow$ & $18 \uparrow$ & $1,9 \uparrow$ \\
\hline
\end{tabular}

Sources of data: SSO Population censuses in the Republic of Macedonia (1948, 1953, 1961, 1971, 1981,1991, 1994 and 2002) [1] [6] [9] [10][11][13] [15] [16] [25]

The data above show that the BUP's prediction for the planned number of population by the end of the planning period was not realized (the BUP predicted a population of 50.000 for 2000 , but according to the 2002 census, there were 43.652 inhabitants). With the GUP projections, it was predicted that in 2010 the population would be 50.546 (the data seems to be unrealistic as it is not based on recent census data). These comparative analyzes indicate that the prediction for the increase in the number of inhabitants was not realized as a result of the calm tendency of the large population growth rate in the period 19611981, reflecting a great mechanical influx and a high increase in a part of the population. $[2][4][5][6][7]$

\section{Analysis of the territorial expansion of the city}

The relationships that the city organism as a conglomerate has with its environment are complex. The developed city is an incentive for its own development, but also for the development of its surroundings and vice versa. Of particular interest is the gravitational area on which the influence of the social, economic, and other functions that are carried out in the city is felt. The size of the gravitational area directly depends on the 
concentration of economic and non-economic facilities and activities in the city. Because of this, Shtip with its gravitational field covers the territory of the East Planning Region and with the excellent traffic connectivity and proximity of Skopje, builds on the created axis of influence, and its position is a prerequisite for synchronized and complementary development of the city. The favorable geographical location, the centrality in east Macedonia and excellent links with Skopje, Veles, Kochani, Radovish, enabled it to develop into a higher-rank centre, as a gravitational zone in a larger area of the territory of the east part of the Republic of Macedonia.

The analysis of the territorial expansion of the city is made with the help of a method of comparing the surfaces of urban areas of the urban plans. The obtained measurements are plan-by-plan and integrally discussed [4][10][11][13].

Table 2. Preview of surfaces of urban areas of urban plans.

\begin{tabular}{|c|c|c|c|c|c|}
\hline $\begin{array}{l}\text { Урбанистички } \\
\text { план }\end{array}$ & $\begin{array}{l}\text { Detailed } \\
\text { Plan, } 1927\end{array}$ & $\begin{array}{lr}\begin{array}{l}\text { State } \\
\text { cadastral } \\
\text { surveys from } \\
1958\end{array} \\
\end{array}$ & $\begin{array}{l}\text { Basic Urban } \\
\text { Plan } \\
\text { Amendments, } \\
1984\end{array}$ & $\begin{array}{l}\text { general } \\
\text { Urban Plan - } \\
\text { Amendments, } \\
1999\end{array}$ & $\begin{array}{l}\text { Draft } \\
\text { General } \\
\text { Urban Plan, } \\
2014\end{array}$ \\
\hline surface area (ha) & 97 & 630 & 2.180 & 2.039 & $2.292,13$ \\
\hline $\begin{array}{l}\text { surface increase } \\
\text { (ha) }\end{array}$ & & $533(549,5 \%)$ & $1550(246 \%)$ & $-141(-6,4 \%)$ & $\begin{array}{l}253,13 \\
(12,4 \%)\end{array}$ \\
\hline
\end{tabular}

Source: author

Detailed Plan, 1927

The area of the 1927 Detailed Plan is 97 ha and it is a reflection of the existing situation of the urban web [4].

\section{General Urban Plan, 1963}

There are not graphic appendices from the 1963 General Urban Plan in the archives of the municipality of Shtip. For the purpose of this research, the information on the boundaries provided for by this plan has been taken from the cadastral surveys of 1958 and it is approximate. Drawing these approximate boundaries gives an area of 630 ha, thus reflecting the existing construction fund. This situation represents a rapid increase from the situation in 1927 by $549.5 \%$, which is a result of the great increase of the industry in the city [11] [13].

\section{Basic Urban Plan - Amendments, 1984}

The amendments of the Basic Urban Plan from 1984 follow the planning concept of the previous plan from 1963 and they make a revision of the planning solution with respect to the current situation and configuration of the terrain. Regarding the planning area, it stipulates an increase of the boundaries of the BUP by 1550 ha. Compared with the planning area from the previous plan, the impact of the population growth rate in this period and the great migration pressure are evident. Because of this, the planner made the development projections for an area which is $246 \%$ larger than the area of the current plan in that period. The boundaries from the plan include zones of illegal housing, with the plan stipulating an expansion to the north and east of the city [11].

\section{General Urban Plan - Amendments, 1999}

The planning area of the General Urban Plan from 1999 follows the situation of the previous plan and makes minor changes regarding the territorial position of the 
boundaries of the city. The subject of analysis in the process of drafting the plan is the situation of irrational land use, with small population density, and unjustifiability of the utilized land. Because of this, the plan revises the boundaries of the BUP and stipulates a reduction in the area by $6.4 \%$, with the aim of adapting the current situation [13].

Draft General Urban Plan, 2014-2024

The planning area of the new General Urban Plan is in draft phase and the procedure for its adoption has not yet been completed. The area stipulated by this plan is $253.13 \mathrm{ha}$, an increase of $12.4 \%$ compared to the current plan.

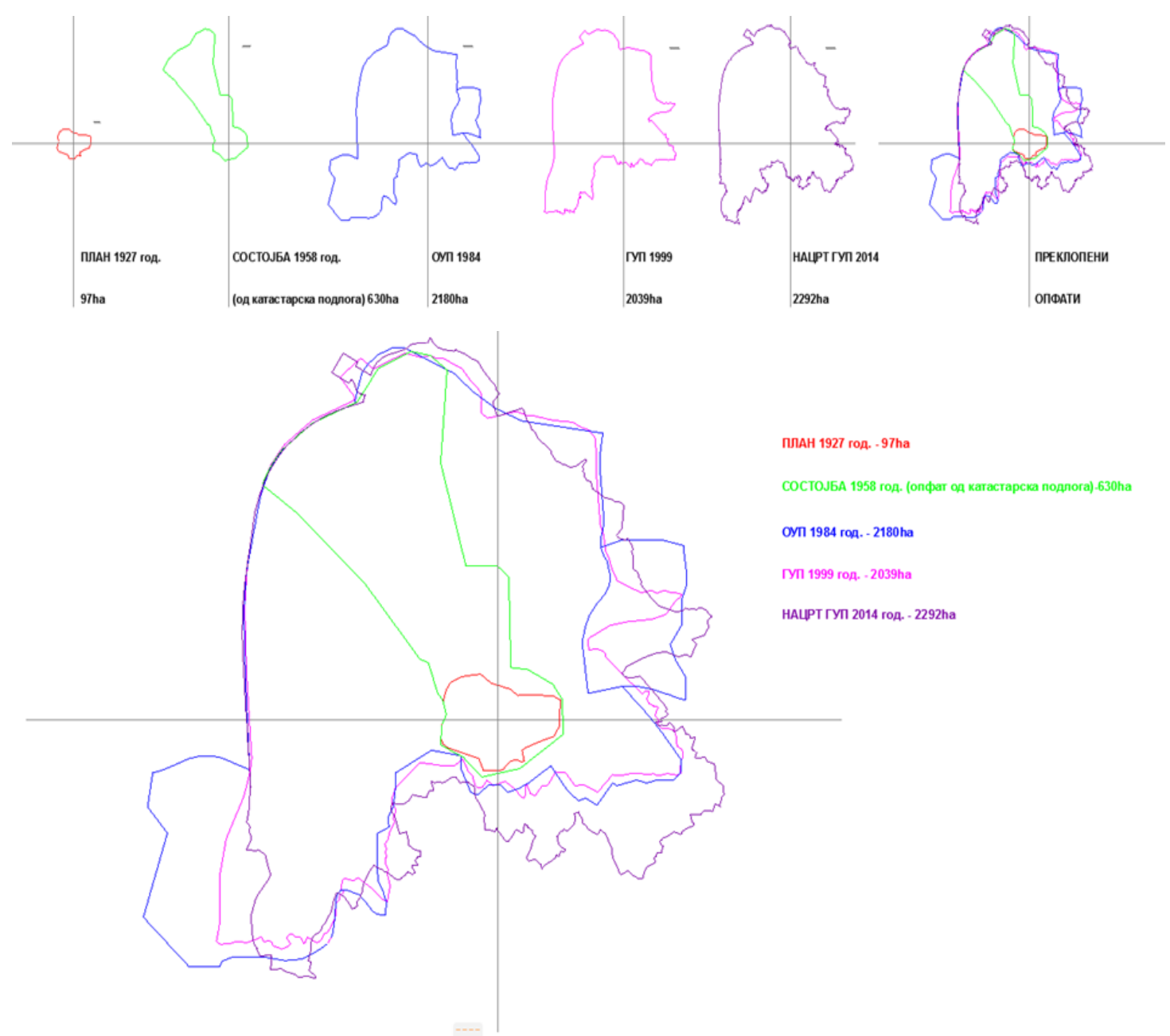

Figure 8. Overlap of planning areas of adopted plans. Source: author [4][10][11][13]

The following graphic display represents an overlap of the planning areas of all urban plans, for a clearer understanding of the boundaries of the spatial expansion of the city [10].

\section{CONCLUSION}

Having in mind all elaborations, it can be perceived that the development line of the city of Shtip, as a result of the planned treatment, begins in 1927, when a city that follows a European model is planned on the current surface of about 97 ha. The development continues along with the next plan in 1963, which stipulates an urban area of about 630 
ha (state established from the cadastral records from 1958 obtained from the municipality of Shtip). During this period, there was a large increase of city boundaries, or about 6.5 times the boundaries of the previous plan. The tendency of the large expansion of the urban area of the city is also strongly emphasized in the 1984 plan, entitled Basic Urban Plan of the city of Shtip which stipulates an urban area of 2.180 ha, which represents a $246 \%$ increase in the city's boundaries from the previous plan. This growth line of the planning areas reaches its culmination with this plan, and in the next it demonstrates a different trend. With the 1999 General Urban Plan-Amendments (which is still valid), the city boundaries are slightly modified to fit the current situation, and for the first time are decreased by $6.4 \%$ compared to the previous plan. The last plan that is subject to analysis is the Draft General Urban Plan, which is still being drafted and adopted, covering an urban area of 2.292,13 ha. This means that with the planning development of the city of Shtip, during a time span of almost 90 years, starting from a present situation of 97 ha in 1927, it has reached a situation of 2.292,13 ha planned urban area. The city's area during this period of analysis stipulates a planning increase of the city's boundaries by more than 23 times.

These figures, presenting the high rate of growth in the boundaries of Shtip (covering its territorial expansion) raise an inevitable question about the politics of sustainable development, rational use of the land and, of course, protection of the agricultural land and forests. This is especially true if we take the current situation with the inventory in 2014 into consideration for the documentation requirements for the development of the new GUP. The inventory shows that the area of developed land within the planned city area of $2.292,13$ ha is only 728 ha, i.e. $1.359,3$ ha (59\%) represent undeveloped land.

The elapsed time, in which the transition process has been going on, has brought about major economic changes which generate structural changes in the city's development plans. The dynamics of this process has implications for the creation of new spatial relationships and conditions the need for planned articulation of the city space. The alteration of spatial constellations necessarily requires the evaluation of the urbanization process, the territorial and morphological development of the city, the re-examination of urban processes, the spatial consolidation and the establishment of a consistent urban model.

Due to the complex structure involving different segments and their interrelations, there is a need of all-inclusive analysis. In this way, we can obtain an integral representation of the occurrence and its meaning in general. The research has to provide the mutual relations, the conflict points and the negative effects of the urban expansion of the city web, at the expense of the elements for sustainable development and rational land use, protection of agricultural land and forests. When determining the proper program-spatial matrix as a tool for spatial planning, apart from all aspects of the existing situation, the inventory, the relations in the urban web, the relations between the urban and rural sections, the needs, the spheres of interest, the possibilities for alternative and multipurpose use, as well as the conflict points in using the land, the developing line should be based on the strategic theses of the European Union for spatial planning. They are mainly oriented towards polycentric and balanced spatial development, integration of the urban and rural environments, territorial integration in the international functional regions, providing competition in regions based on strong local economies, improving communication infrastructure between the population, the community and the economy. This can be done if all aspects of protecting and enhancing the environment and the cultural goods are taken into account [1][4][10][11][12][13] [19][20]. 


\section{REFERENCES}

[1] Agency for Physical Planning. Spatial Plan of the Republic of Macedonia-drafting, Spatial Plan of the East Planning Region 2013-2030-Draft. Skopje: 2016. (Translated from the original: Агенција за планирање на просторот. Просторен план на Република Македонијаразработка, Просторен план на Источен плански регион 2013-2030-Нацрт. Скопје: 2016.)

[2] Government of the Republic of Macedonia. Decision on determining the nomenclature of territorial units for statistics - NUTS No. 19-7957/1, 26th December 2010 "Official Gazette of the Republic of Macedonia" No. 158/2007 I 10/2014. (Translated from the original: Влада на РМ. Одлука за утврдување на номенклатура на територијални единици за статистика HTEC, бр. 19-7957/1, 26 декември 2010 „Службен весник на Република Македонија" бр. $158 / 2007$ I 10/2014.)

[3] Daskalovski V., Markoski, B. (0000) "Economic-functional classification of the settlements in the Republic of Macedonia", Geographic observations, Macedonian Geographical Society, Skopje (Translated from the original: Даскаловски В.,Маркоски Б. (0000) Економско функционална класификација на населбите во Република Македонија, Географски разгледи, Македонско географско друштво, Скопје)

[4] Detailed Urban Plan for the city of Shtip: Municipality of Shtip, 1927. (Translated from the original: Детален урбанистички план за Штип: општина Штип, 1927.)

[5] Donski A. "Cultural objects in Shtip in the time of the visit of Evliya Çelebi" 2012.(Translated from the original: Донски А. „Културните објекти во Штип од времето на посетата на Евлија Челебија“ 2012.)

[6] State Statistical Office Statistics review: Macedonia in numbers - ISSN 1857 - 6761, 2016. (Translated from the original: Државен завод за статистика. Статистички преглед: Македонија во бројки-ISSN 1857 - 6761, 2016.)

[7] State Statistical Office. Statistics review: Population and social statistics - ISSN 1409-8997 ESTIMATION of the population on 30.06.2015 and 31.12.2015 by gender and age, p.62. Skopje, 2016. (Translated from the original: Државен завод за статистика. Статистички преглед: Население и социјални статистики - ISSN 1409-8997 ПРОЦЕНИ на населението на 30.06.2015 и 31.12.2015 според полот и возраста, стр. 62. Скопје, 2016.)

[8] Law on Spatial and Urban Planning. Official Gazette of the Republic of Macedonia: No. 4/1996, 51/2005, 199/2014. (Translated from the original: Закон за просторно и урбанистичко планирање. Службен весник на Република Македонија: бр. 4/1996, 51/2005, 199/2014.)

[9] Ilievski, B. "Ethno-demographic changes in the Bregalnica (Shtip) District in 1913-1918" Scientific gathering "Macedonia and Macedonians in World War I" held at MANU on 11.12.2014. (Translated from the original: Илиевски, Б. „Етнодемографските промени во брегалничкиот (штипскиот) округ во периодот 1913-1918 г.“ Научниот собир „Македонија и Македонците во Првата светска војна“ одржан во МАНУ на 11.12.2014.)

[10] IN-PUMA Institute of Urban Planning, Traffic and Ecology. General urban plan of ShtipDraft: 2017. (Translated from the original: ИН-ПУМА Институт за урбанизам, сообраќај и екологија. Генерален урбанистички план на Штип-Нацрт: 2017.)

[11] Institute for Spatial Planning. Ohrid - Megaproject Shtip. Basic Urban Plan for the city of Shtip - Amendments. Shtip: Assembly of the Municipality of Shtip, 1984. (Translated from the original: Институт за просторно планирање Охрид-Мегапроект Штип. Основен урбанистички план на Штип-измени и дополнувања. Штип: Собрание на општина Штип, 1984.)

[12] Institute for Spatial Planning. Ohrid - Megaproject Shtip. Spatial Plan of Shtip. Shtip: Assembly of the Municipality of Shtip, 1984. (Translated from the original: Институт за просторно планирање Охрид-Мегапроект Штип. Просторен план на Штип. Штип: Собрание на општина Штип, 1984.) 
[13] Public Enterprise for Urban Planning, Construction Site Development "SHTIP PROJECT" Shtip, General Urban Plan of the City of Shtip - Amendments: Assembly of the Municipality of Shtip, 1999. (Translated from the original: Јавно претпријатие за урбанизам, уредување на градежно земјиште „ШТИП ПРОЕКТ“ Штип, Измени и дополнувања на Генерален урбанистилки план на Град Штип: Собрание на општина Штип, 1999.)

[14] Korobar, V.P. "Urban Planning in Macedonia in the last fifty years". Jubilee Proceedings 50 years of the Faculty of Architecture. 1999:90-94. (Translated from the original: Коробар, В. П. (1999) „Урбанистичкото планирање во Македонија во последниве педесет години“. Јубилеен зборник 50 години Архитектонски факултет, стр. 90-94, Скопје.)

[15] "Shtip", Cultural and Historical Guide, Council of the Municipality of Shtip, 2002. (Translated form the original: „Штип“, Културно историски водич, Совет на Општина Штип, 2002.)

[16] SHTIP - tourist newsletter, With a city map. Shtip: Municipality of Shtip, 2011. (Translated from the original: ШТИП - туристички информатор, Со мапа на градот. Штип: Општина Штип, 2011 г.)

[17] Rulebook on Urban Planning Standards and Norms. Official Gazette of the Republic of Macedonia, No. 142/15, 217/15, 222/15, 228/15, 35/16, 99/16, 134/16, 33/17 and 86/18. (Translated from the original: Правилникот за стандарди и нормативи за урбанистичко планирање. Службен весник на Република Македонија, број 142/15, 217/15, 222/15, 228/15, 35/16, 99/16, 134/16, 33/17 и 86/18.)

[18] Siljanoska, J. (2001): Planning aspects of shaping the city space, Phd dissertation, University of Ss. Cyril and Methodius, Faculty of Architecture, Skopje. (Translated from the original: Сиљаноска, Ј. „Планерските аспекти на обликувањето на градскиот простор“, докторска дисертација. Скопје, Универзитет „Кирил и Методиј“, Архитектонски факултет, 2001.)

[19] Council of the European Union. Territorial agenda of the European Union 2020: Towards an inclusive, smart and sustainable Europe of diverse regions. Agreed at the Informal Ministerial Meeting of Ministers responsible for Spatial Planning and Territorial Development, Gödöllö, Hungary 19 May 2011. http://ec.europa.eu/regional_policy/sources/policy/what/territorialcohesion/territorial_state_and_perspective_2011.pdf

[20] Odzaklieska H., Markoski B., Dimitrovska O., Milevski I. Basic methodological postulates for determining ecological footprint in Republic of Macedonia, Proceedings of the 5th Congress of the Ecologists of Macedonia, with international participation, (Ohrid, 19th-22nd October 2016), Special issues of the Macedonian Ecological Society 13, pp. 135-139, Skopje. 2017. ISBN13 978-9989-648-37-3, Original scientific article, available online at: www.mes.org.mk

[21] Vresk M. “Grad u regionalnom i urbanom planiranju”. Zagreb: Školska knjiga, 1990.

[22] https://istokpress.mk/малку-за-историја-на-штип-градот-под-ис/

[23] http://eprints.ugd.edu.mk/.pdf пристапено на 31.03.2019

[24] mk.wikipedia.org/wiki/Општина_Штип

[25] mk.wikipedia.org/wiki/Штип\#Балканските_и_светските_војни

[26] www.stip.gov.mk 